\title{
Liquidity Management and Performance of Deposit Money Banks in Nigeria (1986 - 2011): An Investigation
}

\section{Daniel Bassey Edem}

Department of Business Administration, Faculty of Management Sciences, Cross River University of Technology, Calabar, Nigeria

\section{Email address:}

danielbedem@gmail.com

\section{To cite this article:}

Daniel Bassey Edem. Liquidity Management and Performance of Deposit Money Banks in Nigeria (1986 - 2011): An Investigation. International Journal of Economics, Finance and Management Sciences. Vol. 5, No. 3, 2017, pp. 146-161.

doi: $10.11648 /$ j.ijefm.20170503.13

Received: October 15, 2016; Accepted: December 20, 2016; Published: April 28, 2017

\begin{abstract}
Liquidity and bank performance are key factors in determining the survival, growth, sustainability and performance of a banking system. Mistakes in liquidity planning and implementation can affect banking operations and might exhibit long term effect on the economy. The main aim of this study is to find empirical evidence of the impact of liquidity management on the performance of deposit money banks. 24 banks were surveyed which constitute the entire deposit money banking industry in Nigeria between 1986 and 2011. Secondary data were collected and analysed using SPSS. The study uses descriptive, correlations and inferential statistics. Bank performance in terms of profitability is measured by its return on equity. Three hypotheses are formulated and statistically tested at 5 per cent level of significance using Multiple Linear Regression Analysis. Findings from the empirical analysis show that there is a significant relationship between liquidity management and the performance of Deposit Money Banks in Nigeria. The correlation results reveal positive impacts between return on equity and liquidity management variables: liquidity and cash reserve ratios, whereas loan to deposit ratio shows negative impact. However, the key results indicate that only the banks with optimum liquidity were able to maximize returns. The study concludes that illiquidity and excess liquidity pose problem to bank management operations and recommends that bank should adopt optimum liquidity model for efficiency and effectiveness.
\end{abstract}

Keywords: Liquidity, Management, Performance, Deposit Money Banks

\section{Introduction}

The recent turmoil in the global economic system has revealed some deficiencies in liquidity management of the financial institutions. Financial institutions like banks are seen as the backbone of financial system, providing capital for infrastructure, innovation, job creation and overall development. The fundamental role played by banks in the society does not only affect the spending by individual consumers but also the general growth of the industry.

During the last crisis many banks ran out of liquidity, some raised funds at a large discount in order to meet up with high pressure of demand for urgent cash. Liquidity markets were frozen. Many financial and non-financial institutions had to revisit their corporate governance policies to accommodate market and liquidity risk exposures. Equity prices, foreign exchange rate, commodity prices, interest rate and credit spread exhibited negative impacts on bank performance as returns on investment and net-worth of the businesses fell drastically. A lot of assets were devalued and some banks hardly meet their obligations as and when due or discharge them at exorbitant cost. This influenced the bank's ability in stimulating productive economy evidenced in gradual falling in real Gross Domestic Product. This is why liquidity issues have always been a concern of all the nation's stakeholders across the globe, because no sector of the economy can succeed without sufficient funds. The Central Bank of Nigeria, over the years, precisely since 1958, has formulated excellent policy thrusts to revamp the Nigerian financial system for sustainable economic growth. The policy which came in form of re-capitalisation, merger and acquisition, consolidation all aimed at strengthening the financial system with little or no emphasis on liquidity management efficiency. For instance, the event of 1980s which characterized the unprecedented level of distress reflected by large volume of non-performing loans, insolvency, liquidity 
problem and default in meeting depositors and inter-bank obligations necessitated innovations in banking industry in 1986. This innovation and other banking reforms in Nigeria have not yielded sufficient fruit in stabilising banking industry due to poor implementation or sudden termination of the reforms. Government directive to withdraw the deposits of governments and other public sector institutions in 1989 from banks to Central Bank of Nigeria and several historical distresses in the banking sector are instances of liquidity problems facing the banking industry in Nigeria. However, financial regulators have made conscious efforts to ensure that banks hold more liquid assets than before to help selfinsure against potential liquidity problems. For example, Basel II was recently reviewed to provide for more capital buffer to hedge bank flimsiness as well as a common measure of operational risk.

The purpose of business organization like bank is to maximize profit. Striking a balance between liquidity and bank return is of utmost importance. Many approaches have evolved over the years to measure bank performance such as the use of accounting ratio and econometric approaches. Most commonly approach is accounting ratio like return on investment, return on assets, and net interest margin among others. The aim of this paper is to analysis the impacts of liquidity management on bank Performance in Nigeria.

With this in mind, such essential empirical information is crucial for standardization in the perspective of domestic and international liquidity regulations. Although regulations can make the financial system more resilient to liquidity shocks, standardisation should take into consideration any associated costs to the efficiency of financial intermediation as this could result in higher borrowing costs for other agents in the system. This paper finds evidence, based on data obtained between 1986 and 2011 of a significant relationship between liquidity management and return on equity.

The rest of this work establishes this evidence and framework/related literature as applied in this paper. The empirical results are then presented and policy implications drawn.

\subsection{Statement of the Problem}

Liquidity management and bank performance are key factors in determining the development, survival, sustainability, growth and performance of a banking system and the ability to handle the trade-off between the two is a source of concern for bank managers. For instance, banks make loans that cannot be sold quickly at a high price and also issue demand deposits that allow depositors to withdraw at any time. Such a mismatch of liquidity, in which a bank's liabilities are more liquid than its assets, causes problems for banks when too many depositors attempt to withdraw at once as it affects bank liquidity position. Many banks have investment in safe and high yielding illiquid assets but are tied up in loans. Some banks despite having a lot of assets, the sudden withdrawals and the lack of liquid funds lead to a huge loss as a result of taking out emergency loans. This was identified as the major cause of bank failures and nationalisation in 2008 [9], alongside with inability to make adequate profit. As the basic ingredient of measuring the "going concern" banks for these reasons are developing various policies to stop runs and strategies to improve the liquidity position which are usually neglected in times of favourable business conditions, yet the problem is unsolved. The attempts by bank managers to increase return tend to have negative impact on liquidity which might be dangerous to the banks as this can lead to loss of bank's patronage, goodwill, deterioration of bank's credit standings and might lead to forced liquidation of bank's assets on one hand, and maintaining excess liquidity to satisfy customers' demands might affect the returns on the other hand.

Mistakes in liquidity planning and implementation can affect bank operations and might exhibit long term effect on the economy. Profitability does not translate to liquidity in all cases. A bank may be profitable without necessarily being liquid. So liquidity should be managed in order to obtain an optimal level, that is, a level that avoids excess liquidity which may mean lack of business idea by management [46]. At the same time liquidity level should not fall below minimum requirement as it will lead to the inability of the organization to meet short term obligation that are due.

Consequently this research investigates the impact of liquidity management on the performance of deposit money banks in Nigeria.

\subsection{Objectives of the Study}

The major objective of the study is to investigate the impacts of liquidity management on the performance of deposit money banks in Nigeria between 1986 and 2011. The specific objectives are designed:

i. to examine the impact of liquidity management on the performance of deposit money banks.

ii. to determine the effect of loan to deposit ratio on the performance of deposit money banks.

iii. to assess the effect of cash reserve ratio on the performance of deposit money banks.

\subsection{Research Hypothesis}

Hypothesis I: There is no significant relationship between liquidity management and the performance of deposit money banks.

Hypothesis II: There is no significant relationship between loan to deposit ratio and the performance of deposit money banks.

Hypothesis III: There is no significant relationship between cash reserve ratio and the performance of deposit money banks.

\section{Literature Review}

Liquidity management plays very vital role in the successful functioning of all the banking industries. This is because bank's operations and customer relationship are tied to the availability of liquidity. Liquidity is of major 
importance to both internal and external environments of a financial institution as well as the analysts because of its close relationship with day to day operations of business [11]. In this section the researcher builds up theoretical framework of the study and discusses about the tools, strategies and implications of liquidity management aimed at establishing the relationship between liquidity and bank performance.

The liquidity of a bank is its ability to fund all contractual obligations as they fall due. These may include lending, investment commitments, deposit withdrawals and liability maturities in the normal course of business [7]. Bank for International Settlements (BIS) defines liquidity as the ability of bank to fund increases in assets and meet obligations as they come due, without incurring unacceptable losses. A bank is set to be liquid if it stores sufficient liquid assets and cash together with the ability to raise fund quickly from other sources to enable it to meet its payment obligations and financial commitment in a timely manner. Liquid asset refers to cash transferable assets including investment in securities that are easily realisable at a short notice without loss to the bank. Banks are required to keep certain percentage of their deposits as primary reserves in an account with Central Bank which is used primarily to settle inter-bank indebtedness and also as insurance for depositors.

\subsection{Concept of Liquidity Management}

Liquidity management has assumed strategic position in bank management hierarchy due to its critical nature highlighted by recent market turmoil. It is the core function of revenue generation, lending and payment. Success of any bank depends on level of liquidity that is sufficient for its operation. Inefficient management of liquidity results in serious impairment of banking functions and contagious effect on the economy. A bank is set to be liquid if it stores sufficient liquid assets and cash together with the ability to raise fund quickly from other sources to enable it to meet its payment obligations and financial commitments in a timely manner.

\subsubsection{Asset Theory}

The theory of asset management states that banks must seek high returns, reduce risk and make adequate provisions by holding liquid assets. This theory is in support of the need for holding short term assets to cushion the effect of uncertainties in the banking operations and various needs for liquidity. Banks must lend to borrowers who are willing to pay high interest and unlikely to default on their loans, and raise liquidity required without bearing huge costs. Banks are not only funded by assets but they are largely financed by collateralised borrowing which cannot be relied on during financial distress [14]. This refers to loans that provide the lender with a priority claim on specific asset and a general claim on the debtors' other assets. The amounts of liquid assets to be held depend on the bank's apparent need for liquidity and deposits flow, financial market conditions and monetary policy directions. The concept of asset management has some shortcomings. It focuses on asset side of the balance sheet which makes the theory grossly deficient in the active money markets. The bank and the rate of changes in purchased funding are dependent on the market [42]. It also fails to consider that high returns are associated with high risks. According to Dietrich and Wanzenried, achieving high returns while holding a large portion of liquid assets at a low risk can be difficult as liquid assets are costly and have the tendency of reducing profits [18]. In addition, the assets have to be attractive and easily marketable. Failure to do so has been proven to lead to bankruptcy or the need for an emergency loan. Cash asset is presumed to have no unique role in the process of acquisition and disposal of financial assets but the easiness of exchange for cash balance. The easiness is defined as ratio of stock of cash balances to meeting financial obligations on maturity. The closer assets to maturity, the greater in general are the possibilities of realising them before maturity without risk of significant capital loss. The more liquid a bank is in this sense the greater is its capability to meet its obligations as they fall due. Higher ratio implies better performance, while lower ratio is an indicator of threat to the bank and would tend to inhibit bank performance.

Financial assets such as treasury bills have low risk: the risk of loss of value due to changes in interest rate policies is always very low since they are held in short term bases. Financial assets can be categorised into: running assets, reserve assets along with other liquid assets which are mostly short-term claim e.g. treasury bills and investment assets including long-term claims e.g. bonds [31]; money (cash), stock and bonds [19]; and assets 'held for trading', 'held to maturity investment', 'loans and receivables' and 'available for sale' for treatment purposes [58]. Keneys explained the three motives of holding financial assets to include the transactional, precautionary and speculative motives [36]. The economics and finance literature in support of Keneys' assertion analyse four possible reasons for firms to hold liquid assets: the transaction motive [39]; the precautionary motive [45]; the agency motive [38] and the tax motive [24].

\subsubsection{Trade-Off Theory Liquidity}

This theory has had a great effect on holding liquid assets. Under perfect capital market assumptions holding cash asset neither creates nor destroys value. The bank can always raise funds from capital markets when need arises, there are no transaction costs in raising these funds, and the funds can be raised at a fair price because the capital markets are assumed to be fully informed about the prospects of the bank. According to the Tradeoff theory, banks target an optimal level of liquidity to balance the benefit and cost of holding cash. The cost of holding cash includes low rate of return due to liquidity premium and tax disadvantage. The benefits of holding cash are saving of transaction costs to raise funds in which assets are liquidated to make payments and using of liquid assets to finance its activities and investment where other sources of funding are not available or very expensive [1]. Trade off model explains that, firms with high leverage 
attracts high cost of servicing the debt thereby affecting its profitability and it becomes difficult for them to raise funds through other sources. Holding cash on that point is not only maintained by the smaller firm but also larger firms. So firm size does not matter when the question of bankruptcy interrupt the capital structure decision.

\subsubsection{Shiftability Theory}

This theory emphasizes on marketability of bank assets as a better option for investing funds. The theory views long term financing as a more permanent type of funding by banks. It recognizes decreasing significance of short term self-liquidating loan.

\subsubsection{Commercial Loan Theory}

This is also called real bill doctrine. Its views are that bank funds should be invested in short term self-liquidated loans for working capital purposes. It supports the financing of movement of goods through all the stages of production cycle. This theory has shortcomings such as exclusion of long term loans, inconsistency with the demand for economic development, much emphasis on maturity of bank assets instead of marketability, exclusion of stability of demand deposit which helps banks to undertake long term lending among others.

\subsection{Objectives of Liquidity Management}

Tito Cordella and Haizhou Huang among other financial experts have viewed the following objectives as appropriate but not exhaustive [56]. The specific design of efficient liquidity management is dependent on features specific to individual bank's size, nature and structure as well as the type, extent and complexity of its product. These include: i) ensuring solvency at all times for settlement of all cash outflow commitments (both on- and off-balance sheet) on an ongoing daily basis; ii) ensuing that funding is minimum, by avoiding raising fund at market premiums or through the forced sale of assets; iii) ensuring compliance with the statutory liquidity and reserve requirements through development of adequate management information system and internal control; iv) optimising the refinancing structure and coordinating issuance of own instruments in the money and capital markets; and (v) optimising intra-group cash flows such as liquidity "pooling", to reduce dependency on external refinancing.

The more liquidity is generated the greater the risk of severe losses in attempts to dispose of illiquid assets to meet accidental demands of depositors and borrowers. Torre defines treasury management as a set of techniques that act on the short-term liquidity of a firm and at the same time affect those factors and processes that translate immediately into cash, with the ultimate aim of increasing both the liquidity and profitability of the firm. Liquidity in excess of what is required need to be invested in short term securities pending when it is required. The major problem faced by most businesses is the ability to determine the minimum liquidity level required by the business. Minimum liquidity level assists management to maintain enough liquidity to meet its day-to-day operating expenses.

Optimising liquidity balances require a strong and detailed understanding of the bank's liquidity position across all the currencies, accounts, business lines and counterparties [34]. The process requires four steps - identifying, analysing, managing, and optimising liquidity. They are interdependent, each requiring successful accomplishment of the others. In research conducted by Bordeleau and Graham and similar work in Nigeria by O. B Edem, they found evidence that banks with optimum liquidity maximise returns [12], [20]. The results showed that the relationship takes the form of a downward-concave parabola in that the relationship becomes flat around at the maximum liquidity level.

Comprehensive liquidity management programme therefore requires: a) establishment of sound liquidity management policy, b) improvement of funding strategies, c) development of contingency funding strategies to ensure that liquidity gaps are backed up, d) development of alternative scenarios in liquidity planning and e) measurement of mismatches through gap analysis.

\subsection{Sources of Liquidity}

Financial institutions have increasingly funded loan growth not only by reducing their level of highly liquid investments, but also by seeking alternative funding sources. Funding theories classify sources of liquidity into two namely: Stored liquidity and Purchased liquidity. The deposit money banks fund their operations through the following means:

(a) Asset-based sources: This is a source in which funds are temporarily invested or stored with the hope that they would either mature when liquidity is needed or be sellable without material loss in advance of maturity. Stored liquidity theory is based on three asset liquidity theories - liquid asset, real bill doctrine and shiftability theories of liquidity management [43]. The liquid assets include cash and balances due to other banks, call balance with $\mathrm{CBN}$, balance with other banks at local and foreign, call money funds, short term government securities such as treasury bills, treasury certificates and government bonds near maturity within three years; commercial paper, certificate of deposit and other marketable securities e.g. local and state securities.

(b) Liability-based sources: This is also called purchased liquidity. Bank liabilities include all sources of funds acquired and the main sources of bank funds are (i) deposit accounts (ii) borrowed funds and (iii) long term funds. For example banks receive from large depositors and also borrow from the big investment banks in order to utilise their investment opportunities. The funds are pooled together and then allocated to various earning and nonearning assets as appropriate. It extends to include borrowing from $\mathrm{CBN}$ through discount or advances, call money held for other banks, certificate of deposits, and other liabilities like large time deposits of local and state government and pension funds etc. 
Liability funding theory holds that funds can be purchased from the market at a price and used for profitable investment e.g. lending and other investment. Such markets include inter-bank market in which the excess fund in the counterparty's bank can be lent to members at a cost.25 to 1.00 . However, easiness of this transaction depends on the credit worthiness of the borrowing bank and the economic condition. It is the private last resort for liquidity funding. Other markets include money and capital markets. This is the largest source of liquidity. It is a market for wholesale of financial assets. Commercial papers of varied ratings are sold. In this market pre-maturity assets are also liquidated.

(c) Off balance sheet sources: Kashyap, Rajan, and Stein suggest that banks may also create significant liquidity off the balance sheet through loan commitments and similar claims to liquid funds [35]. This source has become very important in the management and analysis of liquidity. Depending on the transaction and level of interest rate at the period, off balance sheet activities can either increase cash inflow or outflow. For instance, interest rate risk debt can be hedged through an interest rate swap arrangement with a highly rated investment bank. If a fixed rate is higher than the floating rate, the bank receives payment for the difference between the two rates and vice-versa. Hence the cash flow from the derivative portfolio aids in the determination of liquidity. The modern theory of financial intermediation shows bank as playing liquidity creation role, by transforming of short term deposits into long term investment. By investing in illiquid loans and financing them with demandable deposits, banks can be described as pools of liquidity in order to provide households with coverage against consumption shocks.

\subsection{Major Risks Faced by the Banks}

Liquidity planning is an important aspect of bank risk management framework. Liquidity risk refers to the risk that the institution might not be in position to generate sufficient cash flow to make payment, withdrawal and other financial obligations in time. Liquidity risk consists of and can manifest in different dimensions: (a) Funding Risk - bank's inability to raise required fund to meet the desire obligations, occasioned by unanticipated withdrawals/non-renewal of deposits (wholesale and retail) (b) Time Risk - It is the inability of the bank to compensate for non-receipt of expected inflows of funds, i.e. performing assets turning into non-performing assets; and (c) Call Risk - It happens due to crystallisation of contingent liabilities and unable to undertake profitable business opportunities when desirable. A bank is liquid when sufficient funds can be raised, either by increasing liabilities or converting assets, promptly and at a reasonable cost. It includes the potential sale of liquid assets and borrowings from money, capital and Forex markets. Bank liquidity management involves acquiring sufficient liquid asset to meet the bank's obligation to depositors and other stake holders. Banks that make commitments to lend are exposed to the risk of unexpected liquidity demands from their borrowers [27]. The more liquidity is generated, the greater is the possibility and severity of losses associated in attempts to dispose of illiquid assets to meet the liquidity demands of depositor.

\subsubsection{Credit Risk}

Credit risk is the risk that a borrower will default on any type of debt by failing to perform his own part of obligation. It is the cost of replacing cash flow when the borrower defaults. The analysis of the financial soundness of borrowers has been the core banking activity since its inception. Credit risk is the potential financial loss as a result of the failure of customers to honour in full the terms of a loan or contract. This definition includes the risk of loss in portfolio value as a result of migration from a higher risk grade to a lower one. In banking credit risk means the risk that payments may be delayed or not made at all, which can cause cash flow problems and affect a bank's liquidity. Credit risk management involves ways of treating individual liquidity risk factors such as drawing on committed credit lines and operational risk management. The objective of credit risk management generally is to maximise a bank's risk adjusted rate of return by maintaining credit risk exposure within acceptable margins. Credit risk is considered as the principal cause of potential losses and bank failures. Credit risk includes both the risk that a obligor or counterparty fails to comply with their obligation to service debt (default risk) and the risk of a deterioration in the credit standing of the obligor or counterparty. This is one of the major factors influencing bank's performance. Financial condition of the borrower and the current value of any underlying collateral are of considerable interest to banks when evaluating the credit risks [50]. Credit risk management policies should include strict credit estimation, designing effective credit risk system, creating suitable credit risk environment and management processes and developing strategies to limit banks' exposition to credit risk while improving performance and competitiveness of the bank [6]. There are basically three kinds of policies related to credit risk management. The first set is aimed at reducing credit risk, which include policies on concentration and large exposures, diversification, lending to connected parties, and overexposure. The second set aims at classifying assets by mandating periodic evaluation of the collectability of the portfolio of credit instruments. The third set of policies aims to make provision for loss or make allowances at a level adequate to absorb anticipated loss.

\subsubsection{Market Risks}

Banks are exposed to market risk both in the management of trading operations and balance sheets. Market risk management is the determination of the value of liquid assets and formulation of market risk stress scenarios. A bank's market risk exposure is determined by both the volatility of underlying risk factors and the sensitivity of the bank's portfolio to movements in those risk factors [17]. Market 
Risk is the risk of earnings rising from changes in basic economic factors such as interest rates, exchange rates, and bond equity or commodity prices. It is a risk that the value of a portfolio, either investment or trading portfolio, will fall due to the change in value of the market risk factors. There are three common market risk factors to banks and these are liquidity, interest rates and foreign exchange rates. Market Risk Management provides a complete framework for measuring, monitoring and managing liquidity, interest rate, foreign exchange and equity as well as commodity price risk of a bank that needs to be closely integrated with the bank's business strategy. However, market risk can only be hedged but cannot be diversified [50].

\subsubsection{Operational Risk}

Basel II defines operational risk as 'the risk of direct or indirect loss resulting from inadequate or failed internal processes, people and systems or from external events.' Malfunctions of the information systems, reporting systems, internal monitoring rules and internal procedures designed to take timely corrective actions, or the compliance with the internal risk policy rules result in operational risks [8]. Operational risk is an event risk: without an efficient tracking and reporting of risks, some important risks will be ignored, there will be no desire for corrective action and this can result in disastrous consequences. Changes in modern banking environment, such as increased reliance on sophisticated technology, expanding retail operations, growing e-commerce, outsourcing of functions and activities, and greater use of structured finance techniques that claim to reduce credit and market risk have contributed to higher levels of operational risk in banks[57]. The Basel Committee addressed operational risk in its Core Principles for Effective Banking Supervision by requiring supervisors to ensure that banks have risk management policies and processes to identify, assess, monitor, and control or mitigate operational risk. In 2013, the Committee further provided guidance to banks for managing operational risk, in anticipation of the implementation of the Basel III Accord, which requires a standard and common measure for operational risks. However, application of gap analysis, action plan and strategies monitoring can help to address operational risk.

\subsubsection{Interest Rate Risk}

Interest rate risk is the potential loss in a bank's earnings or value due to changes in interest rates. Most of the loans and receivables, term and saving deposits generate revenues and costs that are driven by interest rates. Since interest rates are not stable, so also are such earnings. The combination of a volatile interest rate environment and deregulation, and a growing collection of on-and-off balance sheet products have made the management of interest rate risk a great challenge. Bank regulators and supervisors have placed great emphasis on the appraisal of bank interest rate risk management, particularly since the Basel Committee recommends the implementation of market risk-based capital charges. Banks encounter interest rate risk from four main sources namely re-pricing risk, yield curve risk, basis risk, and optionality
[57]. The primary source of interest rate risk stems from timing differences in the maturity of fixed rates and the repricing of the floating rates of bank assets, liabilities, and offbalance sheet positions. The basic tool used for measuring repricing risk is duration, which assumes a parallel shift in the yield curve. Also, re-pricing mismatches expose a bank to risk deriving from changes in the slope and shape of the yield curve. Yield curve risk materialises when yield curve shifts adversely affect a bank's income or underlying economic value. Another source of interest rate risk is basis risk, which arises from imperfect correlation in the adjustment of the rates earned and paid on different instruments with similar repricing characteristics. When interest rates change, these differences can give rise to unexpected changes in the cash flows and earnings spread among assets, liabilities, and offbalance-sheet instruments of similar maturities or re-pricing frequencies, [60]. Bank asset, liability and off-balance sheet portfolios are another sources of interest risk and should be adequately managed otherwise options can pose significant risk to a banking institution because the options held by customers (both explicit and fixed), are generally exercised at the advantage of the holder and to the disadvantage of the bank.

Broadly speaking, interest rate risk management comprises various policies, actions and techniques that a bank uses to reduce the risk of diminution of its net equity as a result of adverse changes in interest rates from any of the sources mentioned above.

\subsubsection{Foreign Exchange Risk}

Banks conducting foreign exchange operations are also exposed to foreign exchange risk in forms of credit risks such as the default of the counterparty to a foreign exchange contract and time-zone-related settlement risk. Foreign exchange risk is incurring losses due to changes in exchange rates. The loss of earnings may occur due to a mismatch between the value of assets and that of capital and liabilities denominated in foreign currencies or a mismatch between foreign receivables and foreign payables that are expressed in domestic currency. Foreign exchange risk is speculative and can therefore result in a gain or a loss, depending on the direction of exchange rate shifts and whether a bank is surplus or deficit in the foreign currency [57].

Foreign exchange risk is comprised of transaction risk, economic risk and revaluation risk. Transaction risk is the price-based impact of exchange rate changes on foreign receivables and foreign payables. Economic risk or business risk relates to the effect of exchange rate changes on a firm or nation's long-term competitive position. Revaluation risk arises when a bank's foreign currency positions are revalued in domestic currency, and when a parent institution conducts financial reporting or periodic consolidation of financial statements.

\subsubsection{Strategic Risk}

Strategic risk is an array of external events and trends that can devastate a bank's growth path and shareholder value [52]. Strategic risk covers a variety of uncertainties which are 
not financial in nature, but rather credit or operational related caused by macroeconomic factors, industry trends or lapses in a firm's strategic choices which adversely affects the firm's earnings and shareholders'value. Strategic risks often constitute some of a firm's biggest exposures and therefore can be a more serious cause of value destruction.

There are significant events which contribute to strategic risk and can be categorised into seven main classes. These include industry margin squeeze, threat of technology shift, brand erosion, emergence of competitor to gain the lion share of the market value, customer priority shift, and new project failure and market stagnation [52]. The basic concept is to provide a framework for assessing a firm's strategic risks and develop counter measures to address them. An effective strategic risk management approach should embrace both the positive and negative risks. To grasp positive risk involves searching for opportunities and developing plans to act on these opportunities when the needs arise. To stop negative risk on the other hand involves reducing the possibility of occurring and extent of losses; and financing recovery from these losses. However, it is argued that due to the complexity of the concept of strategic risk, no single quantitative measure proves satisfactory in all strategic situations [54].

\subsection{Factors Affecting Liquidity Risk}

There are so many factors affecting liquidity risk. These are: (a) Over extension of credit. The major factors affecting credit extension include slow economic condition, necessity for further credit extension, improper assessment of the borrower's credit profile and the need to avoid cost associated with litigation. The more credits are extended the greater the risk. (b) Mismanagement: This is one factor increasing liquidity risk and such include fraud, un-averted strike resulting in loss of customer's confidence, poor customer's credit rating, flawing of credit standard and self-lending. (c) Non recognition of option risk: The inability of the management to recognize and implement the risk mitigation options increases the liquidity risk. (d) Large undrawn loan commitments: this increases the volume of liquidity in the treasury hence present false liquidity position. This is misleading and affects liquidity planning. Sudden withdrawals of such commitments will result in serious liquidity shortfall. (e) Lack of appropriate liquidity policy and contingent plan: Poor liquidity policy to curb with the problem of liquidity in stress period increases the liquidity risk.

\subsection{Liquidity Measures}

Funding theories show basically two approaches to liquidity measure. These are stock approach and cash flow approach. In stock approach the theory applies ratio in which two variables are related to each other while cash flow approach emphases on the maturity structures of a bank's assets and liabilities as well as on the management of liquidity based on cash flow concept.

\subsubsection{Liquidity Asset Measure}

The common ratios for measuring liquidity assets include among others loan-to-deposit ratio, liquidity ratio, cash to total deposit ratio and loan to liability ratio.

\subsubsection{Liquidity Ratio}

There are a number of measures of liquidity such as current ratio, acid test ratio, debt ratio etc. Liquidity ratio is measured as cash and cash equivalent relative to the total assets. This measures liquidity as information about the general liquidity shock absorption capacity of a bank. The liquid asset includes cash in hand, balance with institutions and money at call and short notice. The total assets include the revaluation of all the assets. As a general rule, the higher the share of liquid assets in total assets, the higher the capacity to absorb liquidity shock, given that market liquidity is the same for all banks in the sample. Nevertheless, high value of this ratio may be also interpreted as inefficiency. Since liquid assets yield lower income, liquidity bears high opportunity costs for the bank. Thus it is necessary to optimise the relation between liquidity and bank profitability performance.

Short term liquidity has been argued to have had some effects on the quality of bank assets especially when used by small banks. It is also argued that large banks using short term liquidity during recession tend to have positive effect on bank earnings. Yet other studies argue that there is negative relationship between short term liquidity and bank earning/returns.

\subsubsection{Loan-to-Deposit Ratio}

This is measured as total loans relative to the total liabilities. A higher ratio means less liquidity position which may affect bank lending while a lower ratio signifies good liquidity position which enables banks to lend and invest. Loan to deposit ratio measure of liquidity has been criticised for ignoring quality and maturity of bank assets and for treating bank assets as having equal degree of liquidity and maturity. Recently, financial analysts argued that off balance sheet funding which offers better benefits have made loan to deposit ratio of liquidity measure unpopular. Other forms of loan ratios include loan to liabilities, Loan losses to net loans and Reserve for loan losses to net loans.

\subsubsection{Cash Reserve Ratio (Cash to Total Deposit Ratio)}

Cash to total deposits is another measure of bank liquidity. It has advantage over others in that the liquid assets are directly related to deposits rather than to loans and advances which form the most illiquid of banks assets. However, the problem of this ratio is that a significant part of the cash assets is not really available for financing of liquidity assets.

\subsubsection{Liability Liquidity (Cash Flow) Measure}

This is the ease with which a bank can issue new debt to acquire clearing balances at reasonable costs. Its measures typically reflect a bank's asset quality, capital base, and composition of outstanding deposits and other liabilities. The following measures are commonly used: (a) Total equity to total assets (b) Risk assets to total assets (c) Loan losses to net loans (d) Reserve for loan losses to net loans (e) The 
percentage composition of deposits (f) Total deposits to total liabilities (g) Core deposits to total assets (h) Federal funds purchased and RPs to total liabilities (I) Commercial paper and other short-term borrowings to total liabilities and (J) Volatile Deposits - the difference between actual current deposits and the base estimate of core deposits.

\subsection{Factors Influencing Liquidity}

A bank's liquidity needs depend significantly on the balance sheet structure, product mix, and cash flow profiles of both on-and off balance-sheet obligations. External events and internal financial and operating risks (interest rate, credit, operational, legal, and reputation risks) can influence the liquidity profile of an institution. The ability of a bank to provide liquidity requires the existence of a highly liquid and readily transferable stock of financial assets. Liquidity and transferability are the key ingredients for such transactions. The liquidity requirement means that financial assets must be available to owners on short notice (a day or less) at par. The transferability requirement means that ownership rights in financial assets must be portable, at par, to other economic agents, and in a form acceptable to the other party [51].

\subsubsection{Short Term Interest Rate}

Short term interest rate affects liquidity management as it is influenced by the monetary policy. When interest rates change, these differences can give rise to unexpected changes in the cash flows and earnings spread among assets, liabilities, and off-balance-sheet instruments of similar maturities or re-pricing frequencies [60]. The Central and world banks have now published average annual interest rates and banks are expected to disclose more detailed financial information for the determination of spread in the banking system without cost. This stresses the importance of interest rate spread. Intermediation spread is an outcome of bank's decision and is affected by micro and macro level factors. Spread is subject to many macro level issues that shape the efficiencies in financial sector performance. It is a reward for liquidity risk earned by transformation of deposit into loan and for selecting and monitoring the right kind of borrowers. Spread provides sufficient margins for the banks to continue its operations in the market. To be relevant banks must manage other risks such as market risk, legal risk, liquidity risk, strategic risk etc. to enable them cover costs of operation and give good returns for equity holders. Interest rate spread or financial intermediation spread is an important indicator for the banking system and the intermediation process. It is associated with cost of financial intermediation. Interest rate spread between lending and deposit rates may be used for making judgment on banks efficiency in individual bank or banking efficiency in overall spread of banking system. Overall spread of banking system can be used for assessing profitability and pricing behaviour of banks while spread between high and low of inter-bank rates can be used for the early indication of change in risk perception. Market competition in the banking sector affects spread. A bigger bank enjoys the benefit of bargaining power over other customers thereby giving the opportunity to widen the spread and indeed increase its profit margin. However, it is obvious that no single bank can extremely dominate loan market due to little product differentiation between banks. There are two markets here - the loan and deposit markets. These markets influence the spread coupled with other environmental factors.

\subsubsection{Macroeconomic Condition}

The recent crisis has highlighted the importance of liquidity as an influence on banks' ability to extend credit and on economic activity. The level of economic activities affects the liquidity holding of a bank. An increase in economic activities of the country indicates that customers demand for loans will increase, and with improved lending activities, banks would be able to generate more profits. Macroeconomic variables like GDP growth rate, short term interest rate, inflation among others affect corporate liquidity holding. In examining the linkages between real economy and bank performance, Laeven and Majnoni find evidence that banks increase provisions when earnings increase, but provisions also increase when GDP growth falls. They investigated how loan loss provisions adjust to changes in GDP growth, bank earnings and loan growth and conclude that banks' provisions increase when earnings are strong; and during recessions to reinforce the business cycle but do not increase provisions during normal business period [37]. The empirical evidences show that banks hold large of liquidity during recession than the normal business period. Furlong and Krainer note that a bank's exposure to economic conditions depends on its portfolio/overall level of lending activity and specific loan exposures to specific industries. Their study identified differences in the correlations of banklevel profitability ratios to state-level averages and interpreted as evidence of the peculiar nature of the linkage between economic condition in a state and the performance of a bank [26]. Jacobson posits that the weaker macroeconomic conditions reduce revenues and business profits and the incomes of households, resulting in households' and businesses' net worth increasing or decreasing slowly.

\subsubsection{Liquidity Ratio}

Risk of liquidity is dangerous to the image of a bank. Bank has to take a proper care to hedge the liquidity risk and at the same time ensure that good percentage of funds is invested in high return generating securities, so that it is in a position to generate profit with provision liquidity to the depositors. Various conscious efforts have been made by researchers to investigate factors that determine the quantity of liquidity holding. Sinkey, Joseph investigated on Bank-specific and macroeconomic determinants of liquidity of English banks and assumed that the liquidity ratio as a measure of the liquidity depends on the following factors: (a) the support from central bank, (b) interest margin (c) bank profitability, (d) loan growth, where higher loan growth indicates increase in illiquid assets, size of the bank, (e) gross domestic product growth as an indicator of business cycle, and (f) short term 
interest rate to capture the monetary policy effect [51].

\subsubsection{Short Term Debt}

Reliance on a few wholesale depositors increases liquidity risk. In the event of the major depositors losing confidence in bank's business operation will mean a drastic fall in liquidity and insolvency. Firms that rely more heavily on short-term liabilities are likely to be more profitable [16]. Evidence in contrast shows that banks that rely more heavily on nondeposit sources of funds experience a significantly larger decline in stock returns [48]. This results in financial flimsiness while measuring default and volatility of bank stock return. However, financing of illiquid assets with short term debt may lead to liquidity shortages and solvency problems.

Liquidity shortages can occur if depositors suddenly demand payments or liquidity holders are not willing to roll over debt. This can result in banks facing huge losses that will restrain future lending and at the extreme can drive contagious bank failures. The reliance of banks on short term wholesale funding to finance the expansion of their balance sheets and excessive leverage has been highlighted as key factors in the build-up of systemic risks. Fisher described a strong links between distressed asset sales and banks' health [23]. The basic mechanism is that given a liquidity or solvency shock, banks start to sell assets, which creates excess supply in asset markets and lowers asset prices. Banks facing urgent need for cash sell their assets at a higher discount to meet up the cash pressure and this affects banks' health.

\subsubsection{Poor Asset Quality}

Poor asset quality affects liquidity as it reduces the value of the asset. Non-performing assets increase the liquidity risk of the bank as it will lead to illiquidity. The higher rate of nonperforming assets the lesser the liquidity, and greater possibility of not meeting the settlement obligations of the affected bank. This also affects the inter-bank market transaction which is on trust and credit worthiness of the counterparty. Such loss of confidence would eventually affect cash inflow especially when wholesale sources seem to be unrealistic.

\subsubsection{Bank Size}

Bank size accounts for the existence of economies or diseconomies of scale. Economic theory suggests that market structure affects firm's performance and if the industry is subject to economies of scale, larger institutions would be more efficient and could provide service at a lower cost. The theory asserts that a firm will enjoy economies of scale up to a certain level, beyond which diseconomies of scale set in. This implies that profitability increases with increase in size, and decreases as soon as there are diseconomies of scale. Thus, there is relationship between the bank size and profitability which may be positive or negative [18] [40] [55] [29] [47].

\subsubsection{Capital}

Capital refers to the owners' fund available to support business operation. Bank capital acts as a buffer in case of adverse condition. Capital is calculated as the ratio of equity to total assets. The ratio measures how much of the banks' assets are funded with owners' fund and is a proxy for capital adequacy of a bank by estimating the ability to absorb the losses. The relationship between capital and profitability is said to be erratic. This is because while some studies show positive relationships [2], [10] and [18], others show negative relationships [32] However, positive relationship implies efficiency of the banks while negative relationship implies inefficiency [53].

\subsection{Bank Performance}

Bank performance is the terms used in relation to its capacity to generate sustainable profitability. For a bank to be successful in its operations, managers must weigh complex trade-offs between growths, return and risk, favouring the adoption of risk-adjusted metrics [49]. Bank's performance measure can be classified into traditional, economic and market-based [2]. For example Stern and Stewart developed a model called Economic Value Added (EVA) which takes into account the opportunity cost for stockholders to hold equity in a bank, measuring whether a company generates an economic rate of return higher than the cost of invested capital in order to increase the market value of the company [59]. There have been a large number of empirical studies on bank performance around the world especially commercial banks but, very little on bank performance has been done in Nigeria.

\subsubsection{Measurement of Bank Performance}

There are two broad approaches used to measure bank performance - the accounting approach which makes use of financial ratios and econometric techniques. Traditionally, accounting methods based primarily on the use of financial ratios have been used for assessing bank performance. The purpose of measuring bank performance is to separate performing banks from nonperforming ones to inform government policy by assessing the effects of deregulation, mergers and market structure on efficiency [10]. Bank performance measurement can also help improve managerial performance by identifying best and worst practices associated with high and low measured efficiency. Bank regulators screen banks by evaluating bank's liquidity, solvency and overall performance to enable them to intervene when there is need to measure the potential problems. According to Ron Best, the main purpose of bank management is to maximize value. Value is the worth of a corporation. The Theory of bank's performance is however complex. There are many ways of measuring performances but financial ratios are commonly used by financial analysts. Financial ratio is a tool that is developed to evaluate financial statements in order to determine the financial performance of a bank.

Accounting standard describes financial statement analysis as an accounting measurement. It is very easy to understand and generally accepted in reflecting the financial performance of banks. Financial analysts employ ratio 
analysis to explain different sort of information regarding the performance and financial condition of banks. By comparing the financial ratios, we are not only reporting how a bank performs, but also how it delivers supplementary information for comparison. Financial analysts argue that the purpose of financial ratios is to measure past performances; determine starting point for planning, estimate future performance and set values as it predicts cash flows and determines financial risk [21]. The theory of ratio analysis is very simple and can be best explained within the framework of a cash flow model. The model is not only developed to determine optimal set of ratios but to explain the ratios being tested. Financial ratio analysis is essential in evaluating credit quality, profitability and liquidity performance [44]. However, ratio as a tool for financial analysis possesses some limitations. Changes often affect multiple ratios and accounting discretion causes the difference in the approaches, therefore the interpretation varies and cannot give answers to all questions by themselves. The commonly used financial ratios derived from the bank financial statement are:

\subsubsection{Return on Investment}

This is measured as Profit before tax/net-worth. It offers the investors opportunity to compare the return on investment with bank deposit rate and other investment returns offered by other business. This is because investors are rationales and want to invest where they are offered higher rate of returns. Attempts have been made by various researchers to analyze return on investment into return on capital employed (ROCE) and return on equity (ROE). ROCE is calculated as Profit before tax/capital employed. Return on Equity is calculated as profit before tax/common stock. The emphasis is that shareholders are more concerned about how much the bank is earning on their equity investment.

\subsubsection{Return on Assets}

Net income gives an idea of how well a bank is doing, but it suffers from one major drawback: It does not adjust for the bank's size, thereby making it difficult to compare how well one bank is doing relative to another. A basic measure of bank performance (profitability) that corrects for the size of the bank is the return on assets (ROA). It is calculated by dividing net income of the bank by the value of its assets. That is, profit before tax / total assets. ROA is a useful measure of how well a bank manager is doing on the job because it indicates how well a bank's assets are being used to generate profits. Brealey, Myers and Marcus affirmed that manager often measure the performance of a firm by the ratio of net income to total assets, otherwise referred to as Return on Asset [13]. Although ROA provides useful information about bank profitability, it is not the most important to equity holders.

\subsubsection{Net Interest Margin}

Another commonly measure of bank performance is called the net interest margin (NIM), the difference between interest income and interest expenses as a percentage of total assets. A bank's primary intermediation function is to issue liabilities and use the proceeds to purchase income-earning assets. If a bank manages its asset and liability in such a way that the bank earns reasonable income on its assets and has low costs on its liabilities, profits will be high. However, how well a bank manages its assets and liabilities is affected by the spread between the interest earned on the bank's assets and the interest costs on its liabilities. Net interest margin measures this spread. If the bank can raise funds with liabilities that have low interest costs and acquire assets with high interest income, then net interest margin will be high, and the bank is likely to make high profit. If the interest cost of its liabilities rises relative to the interest earned on its assets, then the net interest margin will fall, and bank profitability will be affected.

\subsection{Determinants of Bank Performance}

Bank performance in terms of profitability is the ability of a bank to generate income above the cost, in relation to the bank's investment. A sound and profitable banking sector must be able to withstand negative shocks and contribute to the stability of the financial system. Bank profitability is usually expressed as a function of internal and external factors. The internal determinants of bank profitability are also known as bank specific determinants. This can be broadly classified into two - financial statement variables and non-financial statements variables. The financial statement variables which determine bank profitability are: expense management, loan composition and bank credit, composition of bank deposits, market interest rates, bank earning and operating efficiency, changes in capital and liquidity management. The non-financial statement variables which determine bank profitability include number of bank branches, bank size and bank location. Tarawneh in his study measured the performance of Oman commercial banks. The study used Financial Ratio Analysis tool to investigate the impact of asset management, operational efficiency and bank size on the performance of Oman commercial banks. The findings showed that bank performance was strongly and positively influenced by operational efficiency, asset management and bank size and variations in bank profitability can be strongly explained by the level of inflation [55].

The external determinants are variables that are not related to bank management but reflect the economic and legal environments that affect the operation and performance of financial institutions. These factors include: financial regulation, competitive condition, concentration, market share, market growth and ownership. Nicolae, Bogdan and Ihnatove studied the main determinants of banks' profitability in EU27 over the period 2004-2011. They split the study into two large groups: bank-specific (internal) factors and industry specific and macroeconomic (external) factors using ROA and ROAE as proxies for bank profitability. The results show that credit and liquidity risks, management efficiency, the diversification of business, the market concentration/competition and the economic growth have influence on bank profitability, both on ROAA and 
ROAE [41]. Several studies on the determinants of bank profitability show liquidity to be one of the determinants of bank profitability. However, there have been different result reports on the relationship between bank liquidity and profitability. Some research findings argue that banks holding more liquid assets benefit from a superior sensitivity in funding markets, reduce financing costs and increase profitability while others argue that holding liquid assets imposes an opportunity cost on the bank, hence a negative effect on profitability. However, limited number of such study is conducted in Nigeria, specifically to find out the relationship between the liquidity and bank profitability performance. This research therefore investigates the relationship existing between the liquidity and the bank profitability performance in Nigeria.

\subsection{Impact of Liquidity Management on the Performance of Deposit Money Banks}

In attempt to strike a balance between the quantum of liquidity and returns, professionals and scholars have made various efforts to provide a solution to the problem regarding the level of liquidity to hold. An optimal liquidity hypothesis holds that market responses to liquidity-changing events are conditioned by the observed changing levels of the firm's liquidity. There are many liquidity enhancing events or situations that impact on the firm's value: debt/equity issues, sales of assets and loans from interbank markets. The choice of any of these variables affects the level of liquidity. Therefore, dilemma in liquidity management is to achieve desired tradeoff between liquidity and profitability. Profitability and liquidity are of important issues that management of each commercial unit should notice and, ace them into account as their most important duties. Liquidity status is very important for investors and managers as it helps to evaluate a firm's future, estimate investment risk and return and stock price.

Some thinkers believe that liquidity is more important because firms with low profitability or even without profitability can serve economy more than companies without liquidity. Fang, Noe, and Tice in their study find that there exists a positive relationship between liquidity and corporate performance [22]. Gruszcynski, $M$ in his study finds that the degree of success of corporate governance is positively related to firm's financial performance and liquidity [30]. Empirical research on the relationship between liquidity and bank performance of South African banks (1998-2014) was conducted. The study employed the Autoregressive Distributed Lag (ARDL)-bound testing approach and the Ordinary Least Squares (OLS) to examine the connection between net interest margin and liquidity. Two liquidity indicators were used: market liquidity risk and funding liquidity risk. The results reveal a negative significant deterministic relationship between net interest margin and funding liquidity risk. Nevertheless, there is an insignificant co-integrating relationship between net interest margin and the two measures of liquidity [28].

Ali S. Alshatti studied the effect of liquidity management on profitability in Thirteen Jordanian commercial banks from (2005-2012). The liquidity indicators used are investment ratio, quick ratio, capital ratio, net credit facilities/ total assets and liquid assets ratio, while return on equity (ROE) and return on assets (ROA) are the proxies for profitability. The study adopted Augmented Dickey Fuller (ADF) stationary test model to test for a unit root in a time series of the research variables and regression analysis for test of hypothesis. The empirical results show that quick ratio and investment ratio of the available funds have a direct relationship, while capital ratio and liquid assets ratio show an inverse relationship with the banks' profitability [5].

Determinants of bank performance in Thirteen Nigerian banks were studied from 2004 - 2012 using a Generalised Method of Moment (GGM) estimation technique. The study revealed that there is a positive relationship between liquidity and bank performance. The study concludes that bank liquidity, size of the board and debt structure are significant determinants of banks performance in Nigeria. The study urges banks to effectively manage their debt structure and increase liquidity base to achieve higher performance while the central bank should formulate policies that would enhance high liquidity. [48] Liquidity management and the performance of banks in Nigeria from 2000-2010 was also examined. The study applied bank deposit and bank investment variables as proxies for bank performance while cash reserves requirement and cash ratio were used as liquidity management variables. Data were mainly collected from CBN's statistical bulletin and analysed using simple percentages and simple regression model. The results indicate that a strong relationship exists between bank deposit and bank reserve requirement, and bank investment and cash ratio, meaning that successful operations and survival of banks anchored on efficient and effective liquidity management and suggested that banks should devise other measures to reduce illiquidity rather than concentrate purely on deposits [25].

In a related research, the relationship between Liquidity Management and Corporate Profitability in manufacturing firms listed in the Nigerian Stock Exchange was investigated using descriptive statistics. The result shows that liquidity management measured in terms of the companies' Credit Policies, Cash Flow Management and Cash Conversion Cycle has significant impact on corporate profitability and concluded that managers can increase profitability by putting in place good credit policy, short cash conversion cycle and by effective cash flow management procedures [46] Similarly, the effect of liquidity on financial performance of retail merchandising firms in the period of 1998. Q1-2015. Q3 was carried out. The stationarity of series and the cointegration relationship between them are tested by the unit root test and the co-integration test respectively. Cointegration coefficients are estimated by dynamic OLS method, while causal relationships between the series are tested using bootstrap causality test. Results of the test show that the series are co-integrated in the long-run. The results further reveal that while long-run parameters estimated posit 
a significantly positive relationship between financial performance and liquidity, causality test does not indicate any direction of causality between the series.

Bordeleau and Graham in their study investigated the relationship between liquidity and bank profitability by applying Quadratic model in determining the optimum liquidity level of banks in Canada. The results show nonlinear relationship between liquidity and bank profitability [12]. González and Gonzalo Rubio in portfolio choice and effects on liquidity applied econometric model in determining the appropriate liquidity level [29]. Another researcher developed optimum liquidity model to accommodate a multi-stage liquidity need where the liquidity gap and execution cost can be differentiated across stage [15].

Understanding the effect of bank's optimum liquidity level on return on investment is not only significant but crucial in banking while monitoring adequate liquidity to satisfy the regulatory authorities. Banks holding optimum liquid assets benefit from a superior sensitivity in funding markets, reduction in financing costs and increased profitability. However, holding liquid assets involves an opportunity cost because of their low return relative to other assets. This can have negative effect on profitability hence poor corporate performance.

\section{Research Methodology}

\subsection{Population}

The initial work of a researcher is to define the study population explicitly. This represents the theoretical specified aggregation of survey elements. The elements in this sense refer to individuals, materials and organisations about which the researcher collects information for his analysis. The sample population affected in this study is the Deposit Money Banks (Commercial banks) in Nigeria.

\subsection{Sampling and Sample Size}

Judgmental sampling was used in the selection of the sampled population. An informal judgment was made about the sampling units and size base on the knowledge and experience about the population, and the purpose of the study. This helps to observe the elements, research instruments and identify characteristics of the elements. The Deposit money banks were chosen for this study in aggregate. The Research covers the period of twenty seven years $(1986-2011)$.

\subsection{Instrumentation and Data Collection}

Data were collected mainly from secondary sources. Data emanated from banks' financial reports, corporate and scholarly journals, published books and seminar papers/project. The study made use of the financial performance data which were of interest to this researcher. Accessing publicly available data is assumed to be the suitable method for the accuracy of the data. Financial reports and other relevant information of the banks for the period 1986-2011 were obtained from the banks and CBN and some retrieved from the internet by search engines.

\subsection{Methodology}

Data are obtained and analysed in aggregate. The researcher uses multiple linear regression analysis (explanatory approach) with the aid of SPSS in analysing the data collected. It is assumed that the business model is related to funding structure therefore data were obtained through Annual Financial Reports. The stated hypotheses are tested using F-test at 5\% level of significance

The quantitative research approach is adopted to arrive at the findings of the research study. Bank performance and liquidity management variables of the banks are analyzed from 19862011. Descriptive, correlations and inferential statistics are also used. Descriptive statistics depict the mean, standard deviation and coefficient of variation for the chosen variables. It is a snapshot of the samples and their measures and shows the exact position of the data used in the study. Inferential statistics are used to draw conclusions about the reliability and generalization of the findings. In this study, Multiple Linear Regression Analysis has been used as a tool to identify the key relationship between the variables under inferential statistics.

\subsection{Model Specification}

This work is based on theoretical framework discussed in this paper. Liquidity stock approach is adopted in determining the quantum of liquidity and bank returns by examining the ratios of end of year data between 1986 and 2011. Pearson correlation coefficients analysis is applied to identify the nature of relationship between the two variables. The significant relationship between return on equity $(\mathrm{Y})$ and liquidity $(\mathrm{X})$ is tested in which " $\mathrm{X}$ " is the independent variable: liquidity ratio, loan to deposit ratio and cash reserve ratio and can be denoted as $\mathrm{Y}=\mathrm{f}(\mathrm{X})$ showing " $\mathrm{Y}$ " as a function of liquidity. Regression is given as: $\mathrm{Y}=\mathrm{b}_{\mathrm{o}}+\mathrm{b}_{1} \mathrm{x}_{1}+\mathrm{b}_{2} \mathrm{X}_{2}+\mathrm{b}_{3} \mathrm{x}_{3}+\mu$ Where

$\mathrm{Y}=$ Return on Equity

$\mathrm{X}_{1}=$ Liquidity Ratio

$\mathrm{X}_{2}=$ Loan to Total Deposit Ratio

$\mathrm{X}_{3}=$ Cash Reserve Ratio

$b_{1}, b_{2}, b_{3}=$ the slope or the co-efficient of the independent variables.

$\mu=$ stochastic error term.

Specifically, in order to test for key relationship of interest between liquidity and return on equity (ROE), Return on Equity was regressed on liquidity ratio, Loan to deposit ratio and cash reserve ratio.

\section{Analysis of Results}

The results of the hypotheses tested are presented below.

\subsection{Descriptive Statistical Analysis}

Descriptive statistical analysis was performed in this study. Table 1 shows the mean return on equity at $18.02 \%$. It also 
shows that the banks maintained liquidity ratio of $44.70 \%$ during this period and this was higher than the prescribed minimum requirement of $25-30 \%$. The analysis shows that loan to deposit ratio stood at $67.74 \%$. This implies that the banks took a high credit risk which might affect the bank performance as a result of nonperforming loans. The implication is that small businesses may not have access to loan for expansion and in turn can affect the country's economic growth and development. The cash reserve ratio on the other hand was higher than the prescribed ratio of 1.00 to $1.30 \%$ except in 2011 which was less than the prescribed by $3 \%$.

The coefficient of variation value of return on equity was found to be higher than liquidity and loan to deposit ratios. Thus, revealed high volatility of performance measure used in the study. Cash reserve ratio contributed $64 \%$ to return on equity, loan to deposit ratio $15 \%$ and liquidity $20 \%$. The statistical analysis shows that Loan to deposit ratio made the least contribution to the performance of Nigerian deposit money banks.

Table 1. Descriptive statistics.

\begin{tabular}{llll}
\hline Variable & Mean & Std. Deviation & variation \\
\hline Return on Equity Liquidity & 18.0235 & 7.84709 & 0.44 \\
Ratio & 44.6962 & 9.01157 & 0.20 \\
Loan to Deposit Ratio & 67.7385 & 10.09713 & 0.15 \\
Cash Reserve Ratio & 5.5462 & 3.52729 & 0.64 \\
\hline
\end{tabular}

Note: coefficient of the variation is standard deviation/mean

Table 2. Model Summary ${ }^{b}$.

\begin{tabular}{llllll}
\hline Model & R & R Square & $\begin{array}{l}\text { Adjusted R } \\
\text { Square }\end{array}$ & $\begin{array}{l}\text { Std. Error of } \\
\text { the Estimate }\end{array}$ & $\begin{array}{l}\text { Durbin - } \\
\text { Watson }\end{array}$ \\
\hline 1. & $.907^{\mathrm{a}}$ & .822 & .798 & 3.52748 & 1.397 \\
\hline
\end{tabular}

a. Predictors: (Constant), Cash Reserve Ratio, Loan to Deposit Ratio, Liquidity Ratio

b. Dependent Variable: Return on Equity

Table 3. Anova ${ }^{b}$

\begin{tabular}{llllll}
\hline Model & Sum of Squares & df & $\begin{array}{l}\text { Mean } \\
\text { Square }\end{array}$ & F & Sig. \\
\hline 1 Regression & 1265.673 & 3 & 421.891 & 33.906 & .000 \\
Residual & 273.749 & 22 & 12.443 & & \\
Total & 1539.421 & 25 & & & \\
\hline
\end{tabular}

a. Predictor: (Constant), Cash Reserve Ratio, Loan to Deposit Ratio, Liquidity Ratio

b. Dependent Variable: Return on Equity

Table 4. Coefficients ${ }^{a}$.

\begin{tabular}{|c|c|c|c|c|c|}
\hline \multirow[t]{2}{*}{ Model } & \multicolumn{2}{|c|}{$\begin{array}{l}\text { Unstandardized } \\
\text { Coefficients }\end{array}$} & \multicolumn{2}{|c|}{$\begin{array}{l}\text { Standardized } \\
\text { Coefficients }\end{array}$} & \multirow[t]{2}{*}{ Sig. } \\
\hline & B & Std. Error & Beta & $\mathbf{t}$ & \\
\hline 1 (Constant) & -23.351 & 7.643 & & -3.055 & .006 \\
\hline Liquidity Ratio & .546 & .107 & .627 & 5.097 & .000 \\
\hline $\begin{array}{l}\text { Loan to Deposit } \\
\text { Ratio }\end{array}$ & .169 & .078 & .218 & 2.167 & .041 \\
\hline $\begin{array}{l}\text { Cash Reserve } \\
\text { Ratio }\end{array}$ & .995 & .273 & .447 & 3.640 & .001 \\
\hline
\end{tabular}

a. Dependent Variable: Return on Equity

Regression Model generated is given as thus: $\mathrm{Y}=-23.351$

\section{$+.546 * \mathrm{LDQR}+.169 * \mathrm{LTDR}+.995 * \mathrm{CRR}$}

\subsection{Correlation Analysis}

Pearson correlation analysis was conducted to gain an understanding of the relationships existing between the observed and the predicted variables. The results suggest that there is a correlation between the liquidity and bank performance (Appendix). The analysis shows loan ratio correlation coefficient of -.220 at p-value 0.280 with bank return. This reveals weak negative relationship between return on equity and loan to deposit ratio. The analysis has also shown cash reserve ratio correlation coefficient of.775 at p-value. 000 with return on equity. The result implies that there is positive relationship between return on equity and Cash reserve ratio. With regard to the liquidity, the result shows liquidity correlation coefficient of.835 at p-value.000 with return on equity. This reveals positive relationship between return on equity and liquidity. Coefficient determination $r^{2}$ is 0.835 meaning that liquidity contributes about $83.5 \%$ of the returns on equity (Appendix).

\subsection{Regression Results}

Table 4 shows the baseline estimation result in which return on equity is regressed on the balance sheet reliance liquid assets, loan to deposit ratio and cash reserve ratio. The adjusted $\mathrm{R}$ squared 0.80 has shown desirable characteristics with respect to the instrumental variables in use. This means that the model accounts for 80 per cent of the variations in bank performance while remainder 20 percent of the variations which cannot be explained by the model, are caused by other factors. The analysis showed that there was a significant relationship between liquidity management and the performance of deposit money banks in Nigeria.

The multiple correlations coefficients result showed that the Return on equity was constant at -23.351 (Table 4 ). The estimation results all revealed positive coefficients of.546,.169 and.995 for liquidity, loan to deposit ratio and cash reserve ratio respectively and are all statistically significant at 5 per cent level. The results revealed that 1 unit increase or decrease in an independent variable(x) will lead to a unit increase or decrease in the dependent variable(y) while other estimated variables are held constant. This shows positive linear relationship between liquidity management and return on equity as they vary in the same directions. For instance, 1 unit increase in loan to deposit ratio and cash reserve ratio will lead to an increase in return on equity by 0.169 and 0.995 respectively. Similarly, 1 unit increase in liquidity ratio will lead to increase in return on equity by 0.546. This finding confirms the recent studies which find positive relationships between liquidity and bank performance [3], [4], [5], [30], [33] and [45].

\section{Conclusion}

This research work presents empirical evidence of the existing relationship between liquidity management and the 
performance of deposit money banks in Nigeria from 1986 to 2011 using Multiple Linear Regression Model. The results of the investigation revealed that there is a significant relationship between liquidity management and the performance of deposit money banks in Nigeria. The study shows that profitability in terms of return on equity is maximized at optimum liquidity level where cost is efficient. The profit maximization of the banks however, depends on business model adopted by individual banks, its cash inflow and economic condition.

From this study, we can conclude that illiquidity and excess liquidity pose "financial problems" which can easily wear down the bank's return base as both affect bank performance. The desire to maximize high return on investment can cause great illiquidity, which reduces the customers' patronage and loyalty. Therefore, any bank that has the aim of maximizing its return must adopt optimum liquidity model for efficiency and effectiveness.

\section{Recommendations}

Shareholders are rationales and sensitive to information regarding the returns on investment because as retained earnings are sources of capital generation, low return on investment as compared to deposit interest rate may prevent banks from expansion and extension of additional credit to the real economy. The researcher therefore recommends that:

i. Bank managers should identify and monitor key business drivers (e.g. Loan and deposit margins) within the framework of analysis.

ii. Bank officials should be trained in the areas of liquidity management and liquidity changing conditions should not be handled with levity.

iii. Bank managers should be forward looking, and focus on operational efficiency of the banking industry since past trends do not seem to be effective in the face of liquidity crisis.

iv.High quality liquidity assets buffer sufficient to hedge sudden liquidity outflows should be maintained and there should be regular review of prudential guidelines for efficiency.

v. Banks should adopt optimum liquidity model for maximum return on investment, survival, stability, growth and development of banking system in Nigeria.

\section{Appendix}

Table A1. Pearson Correlations Results.

\begin{tabular}{|c|c|c|c|c|}
\hline & Return on Equity & Liquidity Ratio & Loan to Deposit Ratio & Cash Ratio \\
\hline Return on Equity Pearson Correlation & 1 & $.835^{* *}$ & -.220 & $.775 * *$ \\
\hline Sig.(2 tailed) & & .000 & .280 & .000 \\
\hline Sum of Squares and Cross-products & 1539.421 & 1476.407 & -436.196 & 536.612 \\
\hline Covariance & 61.577 & 59.056 & -17.448 & 21.464 \\
\hline $\mathrm{N}$ & 26 & 26 & 26 & 26 \\
\hline Return on Equity Pearson Correlation & $.835 * *$ & 1 & $-.409 *$ & $.665 * *$ \\
\hline Sig.(2 tailed) & .000 & & .038 & .000 \\
\hline Sum of Squares and Cross-products & 1476.407 & 2030.210 & -929.846 & 528.635 \\
\hline Covariance & 59.056 & 81.208 & -37.194 & 21.145 \\
\hline $\mathrm{N}$ & 26 & 26 & 26 & 26 \\
\hline Return on Equity Pearson Correlation & -.220 & $-.409 *$ & 1 & $-.407 *$ \\
\hline Sig.(2 tailed) & .280 & .038 & 2548.802 & .039 \\
\hline Sum of Squares and Cross-products & -436.196 & -929.846 & 101.952 & -362.076 \\
\hline Covariance & -17.448 & -37.194 & 26 & -14.483 \\
\hline $\mathrm{N}$ & 26 & 26 & & 26 \\
\hline Sig.(2 tailed) & .000 & .000 & .039 & \\
\hline Sum of Squares and Cross-products & 536.612 & 528.635 & -362.076 & 311.045 \\
\hline Covariance & 21.464 & 21.145 & -14.483 & 12.442 \\
\hline $\mathrm{N}$ & 26 & 26 & 26 & 26 \\
\hline
\end{tabular}

Correlation is significant at the 0.01 level (2-tailed).**.

Correlation is significant at the 0.05 level (2-tailed).*

\section{References}

[1] Abuzar M. A. Eljelly, (2004). "Liquidity - profitability tradeoff: An empirical investigation in an emerging market", International Journal of Commerce and Management, Vol. 14 Issue 2, pp. 48-61.

[2] Agbeja, O., Adelakun, O. J., Olufemi, F. I.(2015). Capital
Adequacy Ratio and Bank Profitability in Nigeria: A Linear Approach International Journal of Novel Research in Marketing Management and Economics Vol. 2, Issue 3, pp: (91-99), Month: September - December 2015, www.noveltyjournals.com.

[3] Ajibike, John O. and Aremu, Olusegun S. (2015). The Impact of Liquidity on Nigerian Bank Performance: A Dynamic Panel Approach. Journal of African Macroeconomic Review, Vol. 5, No. 2 (C) JournalsBank.com (2015). 
[4] Ali Abdi Sheikhdon (2016). Effect of Liquidity Management On financial Performance of Commercial Banks in Mogadishu, Somalia, International Journal for Research in Business, Management and Accounting.

[5] Ali Sulieman Alshatti (2015). The Effect of the Liquidity Management on Profitability in the Jordanian Commercial Banks, International Journal of Business and Management; Vol. 10, No. 1; 2015 pp. 62.

[6] Ali Sulieman Alshatti (2015). The effect of credit risk management on financial performance of the Jordanian commercial banks, Investment Management and Financial Innovations, Volume 12, Issue 1, 2015.

[7] Amengor (2010) Importance of Liquidity and Capital Adequacy to Commercial Banks". in Victor C. L., Samuel A. and Eric Kofi B. (2013).

http://ijbssnet.com/journals/Vol_4_No_3_March_2013/5.pdf.

[8] Bassis Joel (2010). Risk Management in Banking New York, Wiley; 3 edition January 26, 2010.

[9] Barrell and Davis (2008). The Evolution of the Financial Crisis of 2007-2008 https://www.brunel.ac.uk/data/assets/pdf _file/0015/82212/davisbarrellevolutionpaper.pdf.

[10] Berger Allen N \& David B. Humphrey (1997). Efficiency of Financial Institutions, International Survey and Directions for Future Research.

[11] Bhunia, A. (2010). A trend analysis of liquidity management efficiency in selected private sector industry, Indian steel; International Journal of Research in Commerce and Management, Volume-1,Issue-5;pp9-21.

[12] Bordeleau and Christopher Graham (2010). The Impact of Liquidity on Bank Profitability. www.bank-banque-canada.ca (pp. 1-20). Canada: Financial Stability Deparment, bank of Canada

[13] Brealey, Myers and Marcus (2004). Fundamentals of Corporate Finance, $5^{\text {th }}$ Edition https://wwwundamentalsCorporate-Finance-Stewart-

Richard/dp/0073012386.amazon.com/F

[14] Brunnermeier and Pedersen (2008). Market Liquidity and Funding Liquidity,

http://pages.stern.nyu.edu/ lpederse/papers/Mkt_Fun_Liquidit y.pdf.

[15] Chen, Skoglund, and Cai (2012). Building an Optimal Execution Plan for Liquidity Management Using SAS ${ }^{\circledR}$, SAS Institute Inc., Cary, NC Paper 140-2012.

[16] Christopher F Bauma,b, Dorothea Sch"aferb, Oleksandr Talaverac (2009). The Impact of Financial Structure on Firms' Financial Constraints: A Cross-Country Analysis.

[17] Darryll Hendricks and Beverly Hirtle (1997). Bank Capital Requirements for Market Risk: The Internal Models Approach, FRBNY Economic Policy Review / December 1997.

[18] Dietrich and Wanzenried (2011) Determinants of bank profitability before and during the crisis: Evidence from Switzerland Journal of International Financial Markets, Institutions and Money, 2011, vol. 21, issue 3, pages 307-327.

[19] Douglas Hawks. Types of Financial Assets: Money, Stocks and Bonds .http://study.com/academy/lesson/types-offinancial-assets-money-stocks-bonds.html.
[20] Edem, O. B. (2012) Impact of Efficient Liquidity Management on Commercial Banks in Nigeria. MSc Thesis, Unpublished p.45.

[21] Eugene F. Brigham and Michael C. Ehrhardt (2011). Financial Management: Theory \& Practice, 13th Edition (C) 2011 Published.

[22] Fang, Noe, and Tice (2009), TI Journals, International Journal of Economy, Management and Social Sciences www.tijournals.com Vol (3), No (9), September, 2014. pp. 496-499.

[23] Fisher, A. B. (1995). Creating Stockholder Wealth. Fortune, 132(12), 105-116.

[24] Foley Hartzell, J., Titman, S., and Twite, G. (2007). 'Why do firms hold so much cash? A tax based explanation' Journal of Financial Economics 86,579-607.

[25] Francis A. Bassey, Edu G. Tobi, I. Frank Bassey \& Raymond Enang Ekwere (2016). Academic Research in Accounting, Finance and Management Sciences Vol. 6, No.1, January 2016, pp. 41-48.

[26] Furlong, Mark and Krainer (2007) Subprime Mortgage Delinquency Rates, Federal Reserve Bank of San Francisco Working Paper Series Working Paper 2007-33 http://www.frbsf.org/publications/economics/papers/2007/wp0 7-33bk.pdf Federal Reserve System.

[27] Gatev, E. S. (2007). How Do Banks Manage Liquidity Risks? Evidence from the Equity and Deposit Markets in the fall of 1998 in M. Carey, \& R. M Stulz, The Risks of Financial Institutions. (pp. 105-.

[28] Godfrey Marozva (2015) Liquidity and Bank Performance, International Journal of Economics and Business Research 14(3):453-462·May 2015.

[29] González and Gonzalo Rubio (2011). Portfolio choice and the effects of liquidity Journal of Spanish Economic Associeiton, Volume 2, Issue 1, pp 53-74

[30] Gruszczynski, M. (2006) Corporate Governance and Financial Performance of Companies in Poland, International Advances in Economic Research, Vol. 12, No. 2, May 2006.

[31] Hicks (1967). Monetary Theory and History - an attempt in perspective in Hicks J (ed): Critical Essays in Monetary Theory. Oxford Clarendon Press. http://ijbssnet.com/journals/Vol_4_No_3_March_2013/5.pdf.

[32] Ikpefan Ochei A. (2013) Capital adequacy, management and performance in the Nigerian commercial bank (1986 - 2006) African Journal of Business Management,Vol. 7(30), pp. 2938-2950,

[33] James Ayodele Owoputi (2014) Bank Specific, Industry Specific and Macroeconomic Determinants of Bank Profitability in Nigeria, European Scientific Journal September 2014 edition vol.10, No.25.

[34] Jeanne, O., and Ranciere, (2009). The Optimal Level of International Reserves for Emerging Market Countries a New Formula and Some Applications. C. E. P. R. Discussion Paper 6723.

[35] Kashyap, Rajan, and Stein (2002). Banks as Liquidity Providers: An Explanation for the Co-Existence of Lending and Deposit-Taking, Journal of Finance LVII (1). 
[36] Keneys, J. M. (1937). The General Theory of Employment, Interest and Money. $\mathrm{http} / /$ cas.umkc.edu/economics/people/facultypages/kregel/co urses/econ645/winter2011/generaltheory.

[37] Laeven, L. and G. Majnoni, (2003). "Loan Loss Provisioning and Economic Slowdowns: Too Much, Too late?" World Bank Policy Research Working Paper, no. 2749.

[38] Michael Jensen (1986); Agency Costs of Free Cash Flow, Corporate Finance, and Takeovers. American Economic Review, 1986, vol. 76, issue 2, pages 323-29.

[39] Miller, M. and Orr, D. (1966). A model of the demand for money by firms. Quarterly journal of Economics Vol 80, 413435 .

[40] Naceur, S. B.\&Omran, M. (2011). The effects of bank regulations, competition, and financial reforms on banks' performance.Emerging Markets Review, 12, 1-20.

[41] Nicolae Petriaa, Bogdan Caprarub, Iulian Ihnatovc (2015) Determinants of banks' profitability: evidence from EU27 banking systems, 7th International Conference on Globalization and Higher Education in Economics and Business Administration, GEBA 2013, Procedia Economics and Finance 20 (2015) 518-524.

[42] Nwankwo (1990). Prudential Regulation of Nigerian Banking Publication: Lagos University of London Press 1990. Nill Pbc

[43] Nzotta, S. M. (1999). Theory of Money and Finance. Intercontinental Educational Books and Publishers, Owerri, Abuja, Lagos.

[44] O Donnell and Van Der Westhuizen (2002) Regional Comparisons of Banking Performance in South Africa, South Africa Journal of Economics http://onlinelibrary.wiley.com/doi/10.1111/j.18136982.2002.tb01301.x/abstract.

[45] Oppler, T., Pinkowitz, L., Stulz R., and Williamson, R. (1999, 2016). The Determinants and Implications of Corperate Cash holdings. Journal of Financial Economics Vol. 52, 346.

[46] Owolabi, Sunday Ajao \& Obida, Solomon Small (2012) Liquidity Management and Corporate Profitability: Case Study of Selected Manufacturing Companies Listed on the Nigerian Stock Exchange, Business Management Dynamics Vol.2, No.2, Aug 2012, pp. 10-25.

[47] Rachna Banerjee and Sudipa Majumdar (2014). Profitability Determinants of Commercial Banks in UAE-A Sure Model Approach, Conference Paper: 3rd Asian Business Research Conference, At Insead, Volume: 3.
[48] Raddatz Claudio(2010). When the Rivers Run Dry: Liquidity and the Use of Wholesale Funds in the Transmission of the US Subprime Crisis. Policy Research Working Paper; No. 5203. World Bank, Washington, DC. (C) World Bank.

[49] Ralph C. Kimball (1998). Economic Profit and Performance Measurement in Banking

https://www.bostonfed.org/publications/new-englandeconomic-review/1998-issues/issue-july-august1998/economic.

[50] Santomero, A. M. (1997). Commercial Bank Risk Management: an Analysis of the Process. Wharton Financial Institutions Center, University of Pennsylvania.

[51] Sinkey, Joseph F, JR. (1998). Commercial Bank Financial Management. https://www.amazon.com/Commercial-BankFinancial-Management-6th/dp/0130909106.

[52] Slywotzky, A. and J. Drzik (2005). "Countering the Biggest Risk of All," Harvard Business Review, April 2005, pp. 7888 .

[53] Staikouras C. K and Greece G. E. Wood (2004) Determinants of European Banks Profitability, International Business and Economics Journal Vol.3 No.

[54] Stephen Gates (2006). Incorporating Strategic Risk into Enterprise Risk Management: A Survey of Current Corporate Practice, Journal of Applied Corporate Finance, Volume 18, Issue 4, Pages 81-90.

[55] Tarawneh, M. (2008). A Comparison of Financial Performance in the banking sector: some evidence from Omani Commercial Banks. International Research Journal of Finance and Economics 3, 105-110.

[56] Tito Cordella and Haizhou Huang (2000). Liquidity Management and Trading in the Interbank Market www.lacea.org/meeting2000.htm.

[57] Van Greuning, Hennie; Brajovic Bratanovic, Sonja (2009) Analyzing Banking Risk: A Framework for Assessing Corporate Governance and Risk Management, $3^{\text {rd }}$ Ed. The World Bank, Washington D. C.

[58] Wikipedia, https://en.wikipedia.org/wiki/Financial_asset

[59] Worthington, Andrew and West, Tracey (2001) Economic Value-Added: A Review of the Theoretical and Empirical Literature. Asian Review of Accounting 9(1):pp. 67-86.

[60] Wright David M and Houpt, James V (1996). An analysis of commercial bank exposure to interest rate risk Federal Reserve Board, Board of Governor Federal Reserve System. 